\title{
Penggunaan Fukushi “Chittomo, Kesshite dan Zenzen" Oleh Orang Jepang di Kota Nishinomiya, Hyogo
}

\author{
Ni Kadek Rusida Dewi ${ }^{1 *}$, Renny Anggraeny ${ }^{2}$, I Nyoman Rauh Artana ${ }^{3}$ \\ ${ }^{[123]}$ Program Studi Sastra Jepang Fakultas Ilmu Budaya \\ ${ }^{1}$ [rusidauzikii@gmail.com] ${ }^{2}$ [anggraeny0309@yahoo.co.jp] \\ 3 [nyoman_rauhartana@unud.ac.id] \\ *Corresponding Author
}

\begin{abstract}
The title of this research is "The use of Adverbs 'Chittomo', 'Kesshite' and 'Zenzen' by Japanese People in Nishinomiya City, Hyogo". This research aims to know the structure, function, meaning and usage of adverbs "chittomo, kesshite and zenzen" based on the results of questionnaire. This research uses quantitative method with the questionnaire as data source. Structural and functional analysis using Verhaar (2010) word structure theory. Meaning analysis uses Chaer (2014) contextual meaning theory, which refers to the concepts of "chittomo", "kesshite" and "zenzen" by Sunakawa (1998) and Makoto (2003). The results of this research indicated that "chittomo" can be combined with a negative form. Found 27 data "chittomo" to explain verbs, 25 data explain adjectives and 3 data to explain nouns. "Chittomo" contains the meaning of negation, personal judgment and dissatisfaction of a thing. Then "kesshite" can be combined with negative form and prohibition. Found 50 data "kesshite" explain verbs, 8 data explain adjectives and 2 data to explain nouns. "Kesshite" expresses the meaning of negation, the determination or strong desire of speaker and expression of prohibition. Furthermore, "zenzen" can be combined with negative or positive forms. Found 30 data "zenzen" explain verbs, 29 data explain adjectives and 5 data to explain nouns. "Zenzen" has the meaning of negation, personal judgment and dissatisfaction of a thing.
\end{abstract}

Keywords : fukushi, function, meaning

\section{Abstrak}

Penelitian ini berjudul "Penggunaan Fukushi Chittomo, Kesshite dan Zenzen oleh orang Jepang di Kota Nishinomiya, Hyogo", bertujuan untuk mengetahui struktur, fungsi, makna dan penggunaan dari fukushi "chittomo, kesshite dan zenzen" berdasarkan hasil kuesioner. Penelitian ini menggunakan metode kuantitatif dengan kuesioner sebagai sumber data. Analisis struktur dan fungsi menggunakan teori struktur kata keterangan Verhaar (2010). Analisis makna menggunakan teori makna kontekstual Chaer (2014), yang mengacu pada konsep chittomo, kesshite dan zenzen oleh Sunakawa (1998) dan Makoto (2003). Hasil penelitian ini menunjukkan bahwa chittomo dapat digabungkan dengan bentuk negatif. Ditemukan 27 data chittomo untuk menerangkan kata kerja, 25 data menerangkan kata sifat dan 3 buah data menerangkan kata benda. Chittomo mengandung makna penegasian, penilaian secara pribadi dan ketidakpuasan akan suatu hal. Kemudian kesshite dapat digabungkan dengan bentuk negatif dan larangan. Ditemukan 50 data kesshite menerangkan kata kerja, 8 buah data menerangkan kata sifat dan 2 buah data menerangkan kata benda. Kesshite mengekspresikan makna penegasian, tekad dan keinginan kuat pembicara dan ekspresi larangan. Selanjutnya, zenzen dapat digabungkan dengan bentuk negatif ataupun positif. Ditemukan 30 data zenzen menerangkan kata kerja, 29 data menerangkan kata sifat dan 5 buah data menerangkan kata benda. Zenzen memiliki makna penegasian, penilaian secara pribadi dan ketidakpuasan akan suatu hal.

Kata kunci : fukushi, fungsi, makna 


\section{Latar Belakang}

Kata keterangan biasanya digunakan ataupun ditemukan dalam komunikasi secara langsung maupun tidak langsung. Chaer (2011:190) mengungkapkan bahwa kata keterangan memberikan penjelasan pada kalimat atau bagian kalimat lain. Kata keterangan atau adverbia dalam bahasa Jepang dikenal dengan istilah fukushi. Fukushi merupakan kata-kata yang memiliki fungsi untuk menerangkan verba, adjektiva, dan adverbia lainnya, tidak mengalami perubahan bentuk ketika digunakan dalam kalimat serta berfungsi untuk menyatakan keadaan atau derajat suatu aktivitas, suasana dan perasaan pembicara (Masuoka dan Takubo, 1992:41). Dalam bahasa Jepang fukushi chittomo, kesshite dan zenzen memiliki kemiripan makna ketika diartikan ke dalam bahasa Indonesia yaitu "sama sekali tidak" dan "tidak sama sekali". Apabila dilihat dari segi tataran ilmu semantik bagi penutur asli bahasa Jepang, fukushi tersebut akan dapat segera dipahami makna dan maksud yang ingin disampaikan lawan bicara. Namun, bagi penutur yang merupakan bukan penutur asli bahasa Jepang atau pembelajar bahasa Jepang akan mengalami kesulitan dalam memahami penggunaan, fungsi dan makna ketiga fukushi tersebut. Fukushi chittomo, kesshite dan zenzen meskipun memiliki makna yang mirip atau-pun sama dalam bahasa Indonesia, agar tidak terjadi kesalahan dalam penggunaannya tetap perlu diperhatikan bagaimana konteks penggunaan yang tepat dari ketiga fukushi tersebut.

Penelitian ini membahas tentang fungsi, makna dan penggunaan fukushi chittomo, kesshite dan zenzen oleh orang Jepang di kota Nishinomiya, Hyogo, Jepang. Adanya variasi atau perbedaan penggunaan fukushi chittomo, kesshite dan zenzen dalam percakapan sehari-hari oleh orang Jepang di kota Nishinomiya,
Hyogo, menjadi alasan utama sehingga penulis tertarik untuk menganalisis fungsi, makna dan penggunaan dari fukushi chittomo, kesshite dan zenzen oleh orang Jepang di kota Nishinomiya, Hyogo berdasarkan hasil kuesioner yang telah didapatkan.

\section{Pokok Permasalahan}

Berdasarkan uraian latar belakang tersebut, maka rumusan masalah penelitian ini adalah sebagai berikut :

a. Bagaimanakah fungsi fukushi chittomo, kesshite dan zenzen yang digunakan dalam percakapan seharihari oleh orang Jepang di kota Nishinomiya, Hyogo?

b. Bagaimanakah makna fukushi chittomo, kesshite dan zenzen yang digunakan dalam percakapan seharihari oleh orang Jepang di kota Nishinomiya, Hyogo?

c. Bagaimanakah penggunaan fukushi chittomo, kesshite dan zenzen yang digunakan dalam percakapan seharihari oleh orang Jepang di kota Nishinomiya, Hyogo?

\section{Tujuan Penelitian}

Secara umum penelitian ini bertujuan untuk memperkaya kazanah penelitian dalam bidang linguistik bahasa Jepang mengenai fukushi atau adverbia. Secara khusus, penelitian ini bertujuan untuk mengetahui fungsi, makna dan penggunaan dari fukushi chittomo, kesshite dan zenzen oleh orang Jepang di kota Nishinomiya, Hyogo berdasarkan sumber data berupa hasil kuesioner yang telah didapatkan.

\section{Metode Penelitian}

Metode dan teknik pengumpulan data yang digunakan dalam penelitian ini adalah metode kuantitatif. Pengumpulan data dilakukan dengan cara membagikan 43 kuesioner di kota Nishinomiya, perfektur Hyogo. Selain itu, digunakan 
juga metode simak dan teknik catat. Metode dan teknik analisis data yang digunakan adalah metode deskriptif analisis. Kemudian, metode dan teknik penyajian hasil analisis data yang digunakan adalah metode formal dan metode informal. Teori yang digunakan untuk memecahkan permasalahan adalah teori sintaksis oleh Verhaar (2010) dan teori makna kontekstual oleh Chaer (2014) yang mengacu pada konsep fukushi chittomo, kesshite dan zenzen oleh Sunakawa (1998) dan Makoto (2003).

\section{Hasil dan Pembahasan}

Berdasarkan hasil kuesioner yang telah dibagikan sebelumnya di kota Nishinomiya, perfektur Hyogo, Jepang terdapat 57 data berkaitan dengan chittomo, 64 data berkaitan dengan kesshite dan 68 data yang berkaitan dengan zenzen.

\subsection{Fungsi dan Makna Chittomo}

Chittomo memiliki fungsi untuk menerangkan kata benda, kata kerja dan kata sifat yang diikuti dengan bentuk negatif, serta mengandung makna penegasian, penilaian pribadi dan kekecewaan yang dirasakan pembicara. Chittomo memiliki arti "sedikit pun tidak" dan "sama sekali tidak". Hasil analisis menunjukkan data sebagai berikut.

\begin{tabular}{llll} 
(1) 明日 & 遊ぶ & 約束 & \multicolumn{2}{c}{} \\
Ashita & asobi & yakusoko & wo \\
Besok bermain & janji & AKU \\
& & のに \\
してた & & noni, \\
shiteta & & $\begin{array}{l}\text { padahal, } \\
\text { melakukan-BTK.LAM }\end{array}$
\end{tabular}

$$
\begin{array}{ll}
\text { が } & \text { ない。 } \\
\text { ga } & \text { nai. } \\
\text { NOM } & \text { ada-BTK.NEG. }
\end{array}
$$

Terjemahan : "Padahal sudah berjanji besok akan bermain tetapi sama sekali tidak ada menghubungi."

Data (1), fukushi chittomo berfungsi untuk menerangkan kata benda renraku yang memiliki arti "menghubungi" dan "kabar". Chittomo ketika menerangkan kata benda diikuti dengan bentuk negatif (-nai). Sebelum penggunaan chittomo data (1) pembicara menyatakan alasan yang menunjukkan makna kekecewaan. Data (1), menunjukkan situasi ketika pembicara mengungkapkan kekecewaannya terhadap teman atau saudara yang sudah berjanji akan bermain besok tetapi sama sekali tidak menghubungi atau-pun tidak memberikan konfirmasi terkait janji tersebut. Sehingga chittomo data (1), mempunyai fungsi dan makna untuk menerangkan kata benda yang diikuti dengan bentuk negatif, mengandung makna penegasian serta kekecewaan yang dialami oleh pembicara.

\subsection{Fungsi dan Makna Kesshite}

Kesshite memiliki fungsi untuk menerangkan kata benda, kata kerja bentuk biasa dan kata sifat yang mengandung makna penegasian, tekad atau keinginan kuat pembicara, dan mengandung makna ekspresi larangan. Kesshite memiliki arti "sama sekali tidak", "tidak akan", dan "jangan pernah". Hasil analisis menunjukkan data sebagai berikut.

(2)

$\begin{array}{lll}\text { 決して } & \text { 彼 } & \text { を } \\ \text { Kesshite } & \text { kare } & \text { wo } \\ \text { Tidak pernah } & \text { dia (laki-laki) } & \text { AKU }\end{array}$


付き合って

tsukiatte

menjalin hubungan BTK.SED

$\begin{array}{ll}\text { は } & \text { ない。 } \\ \text { wa } & \text { nai. } \\ \text { TOP } & \text { ada.BTK.NEG. }\end{array}$

Terjemahan : "(Saya) tidak pernah menjalin hubungan dengan dia (lakilaki)."

Data (2), kata kerja dasar yang digunakan adalah tsukiau, memiliki arti "menjalin hubungan" merupakan kata kerja golongan I atau godan doushi dengan akhiran bentuk kamus (-u). Tsukiau mengalami perubahan bentuk menjadi kata kerja bentuk sedang terjadi (-te) yang diikuti dengan bentuk negatif (-nai). Kesshite data (2), berfungsi untuk menerangkan kata kerja yang diikuti dengan bentuk negatif. Selain itu, kesshite juga memiliki fungsi untuk menekankan makna penegasian terhadap suatu peristiwa yang berkaitan dengan tekad atau keinginan pembicara. Keinginan pembicara tersebut dapat dipahami dari ungkapan penegasian pembicara yang membantah dengan tegas bahwa pembicara tidak memiliki keinginan sama sekali untuk menjalin hubungan (misalnya berpacaran) dengan laki-laki yang di maksud pembicara.

\subsection{Fungsi dan Makna Zenzen}

Zenzen memiliki fungsi untuk menerangkan kata benda, kata kerja bentuk biasa dan kata sifat yang mengandung makna penegasian, penilaian pribadi pembicara dan kekecewaan yang dirasakan pembicara. Zenzen memiliki arti "sama sekali tidak", "benar-benar", dan "sangat". Hasil analisis menunjukkan data sebagai berikut.

\section{（3）傘 を 持つて}

Kasa wo motte

Payung AKU membawa-BTK.SED

$\begin{array}{ll}\text { きた } & \text { のに、 } \\ \text { Kita } & \text { noni, } \\ \text { datang-BTK.LAM } & \text { padahal, }\end{array}$

$\begin{array}{lll}\text { 全然 } & \text { 晴れている } & \text { ね。 } \\ \text { zenzen } & \text { hareteiru } & n e . \\ \text { sangat } & \text { cerah-BTK.SED } & \text { PAR. }\end{array}$

Terjemahan : "Padahal datang membawa payung tetapi (cuaca) sangat cerah ya."

Data (3), kata kerja dasar yang digunakan adalah hareru, memiliki arti "cerah". Kata kerja hareru merupakan kata kerja golongan II atau ichidan doushi dengan akhiran bentuk kamus (eru). Hareru mengalami perubahan bentuk menjadi kata kerja bentuk (-te), yang menunjukkan kejadian sedang terjadi atau sedang berlangsung (harete iru). Zenzen data (3), berfungsi untuk menerangkan kata kerja dalam bentuk positif. Jadi zenzen data (3), memiliki fungsi untuk menerangkan kata kerja bentuk positif serta menekankan makna penegasian pada kejadian yang tidak diperkirakan sebelumnya oleh pembicara. Data (3), menunjukkan bahwa ada kemungkinan sebelum pergi ke suatu tempat pembicara telah membaca informasi mengenai ramalan cuaca yang menunjukkan bahwa hari ini akan turun hujan, sehingga pembicara pergi membawa payung. Namun, di luar perkiraan pembicara sebelumnya, ternyata hari ini sama sekali tidak turun hujan dan (langit) sangat cerah.

\subsection{Penggunaan Chittomo, Kesshite dan Zenzen oleh orang Jepang di kota Nishinomiya, perfektur Hyogo. \\ Berikut merupakan penggunaan fukushi chittomo, kesshite dan zenzen}


oleh orang Jepang di kota Nishinomiya, perfektur Hyogo berdasarkan hasil kuesioner yang telah didapatkan. Hasil analisis menunjukkan data sebagai berikut.

(4) あの政治家は.....誠実ではない。

\begin{tabular}{|c|c|}
\hline Fukushi & $\begin{array}{c}\text { Jumlah } \\
\text { Responden }\end{array}$ \\
\hline Chittomo & 36 \\
\hline Kesshite & 14 \\
\hline Zenzen & 22 \\
\hline
\end{tabular}

Tabel 1. Hasil Penggunaan Fukushi

$\begin{array}{lll}\text { あの } & \text { 政治家 } & \text { は } \\ \text { Ano } & \text { seijika } & w a \\ \text { Itu } & \text { politikus } & \text { TOP }\end{array}$

$\begin{array}{ll}\text { 決して } & \text { 誠実 } \\ \text { kesshite } & \text { seijitsu } \\ \text { Tidak pernah } & \text { jujur }\end{array}$

ではない。

dewa nai.

KOP.NEG.

Terjemahan : "Politikus itu tidak pernah jujur."

Data (4), fukushi yang paling sesuai untuk melengkapi kalimat adalah kesshite (Makoto, 2003:45). Kesshite data (4), berfungsi untuk menerangkan $n a$ keiyoushi atau kata sifat (na) yang diikuti dengan bentuk negatif (-dewa nai). Kata sifat yang diterangkan adalah seijitsu, memiliki arti "jujur". Kesshite data (4), memiliki arti "tidak pernah" serta mengandung makna penegasian. Penegasian tersebut dipahami berdasarkan penilaian pribadi pembicara yang memiliki anggapan bahwa politikus yang dimaksud tidak pernah berkata jujur atau tidak pernah berkata yang sebenarnya. Berdasarkan penjelasan tentang struktur dan makna kesshite yang diungkapkan oleh Makoto (2003:45), kesshite ketika digunakan dalam kalimat data (4) tidak dapat digantikan dengan chittomo dan zenzen. Hal tersebut dikarenakan chittomo dan zenzen tidak memiliki fungsi untuk menunjukkan atau-pun menerangkan makna tekad atau keinginan kuat pembicara.

Hasil kuesioner data (4), menunjukkan 36 responden menjawab chittomo, 22 responden menjawab zenzen dan 14 responden menjawab kesshite. Berdasarkan hasil kuesioner data (4) tersebut, menunjukkan ada kemungkinan besar penggunaan kesshite dapat digantikan dengan chittomo atau-pun zenzen ketika digunakan dalam percakapan sehari-hari oleh orang Jepang di kota Nishinomiya, Hyogo. Penggu-naan kesshite data (4), menunjukkan keinginan kuat pembicara yang mencoba meyakinkan lawan bicaranya berkaitan dengan informasi mengenai politikus yang dimaksud pembicara. Namun, berdasarkan hasil kuesioner menunjuk-kan bahwa penggunaan chittomo atau zenzen lebih tepat digunakan pada data (4), dikarenakan struktur chittomo dan zenzen juga dapat digabungkan dengan kata sifat yang diikuti dengan bentuk negatif. Selain itu, chittomo dan zenzen juga memiliki arti "sama sekali tidak", yang memiliki makna penegasian dan penilaian pribadi pembicara terhadap suatu hal. Chittomo dan zenzen yang tidak memiliki fungsi untuk menerang-kan keinginan atau keyakinan kuat pembicara terhadap suatu hal justru menjadi pilihan orang Jepang untuk memperhalus makna dalam kalimat.

\section{Simpulan}

Hasil analisis data menunjukkan bahwa fukushi chittomo, kesshite dan zenzen dapat digabungkan dan menerangkan kata benda, kata sifat serta kata kerja. Ketiga fukushi tersebut memiliki kemiri- 
pan arti yaitu, "sama sekali tidak", memiliki fungsi dan makna yang sama yaitu, untuk menekankan penegasian dan menerangkan penilaian pribadi pembicara.

Chittomo dapat digabungkan dengan kata benda, kata sifat dan kata kerja dalam bentuk negatif. Berdasarkan hasil kuesioner terdapat 27 data chittomo yang berfungsi untuk menerangkan kata kerja, 25 data menerangkan kata sifat dan 3 buah data menerangkan kata benda. Chittomo memiliki arti "sedikit-pun tidak" dan "sama sekali tidak". Chittomo memiliki tiga makna yaitu, 1) makna penegasian, 2) makna penilaian pribadi pembicara, dan 3) makna kekecewaan yang dirasakan pembicara.

Kesshite dapat digabungkan dengan kata benda, kata sifat serta kata kerja. Kesshite dapat digabungkan dengan kata kerja bentuk biasa dengan syarat kata kerja tersebut harus diikuti dengan pola kalimat yang menunjukkan ekspresi larangan. Berdasarkan hasil kuesioner terdapat 50 data kesshite, berfungsi untuk menerangkan kata kerja, 8 buah data menerangkan kata sifat dan 2 buah data menerangkan kata benda. Kesshite memiliki arti "tidak akan", "jangan pernah" dan "sama sekali tidak". Kesshite memiliki tiga makna, yaitu 1) makna penegasian, 2) makna tekad atau keinginan pembicara, dan 3) makna ekspresi larangan.

Zenzen dapat digabungkan dengan kata sifat, kata kerja yang diikuti dengan bentuk negatif atau-pun positif. Berdasarkan hasil kuesioner terdapat 30 data zenzen, berfungsi menerangkan kata kerja, 29 data menerangkan kata sifat. Selain itu, terdapat 5 buah data yang menggabungkan zenzen dengan kata benda dalam bentuk negatif. Zenzen memiliki arti "sama sekali tidak", "benar-benar" dan "sangat". Zenzen memiliki tiga makna, yaitu 1) makna penegasian, 2) makna penilaian pribadi pembicara, dan 3) makna kekecewaan yang dirasakan pembicara.

Penggunaan chittomo, kesshite dan zenzen yang dapat saling menggantikan dikarenakan ketiga fukushi tersebut memiliki kemiripan dari segi struktur, fungsi dan makna. Chittomo, kesshite dan zenzen dapat digabungkan dengan bentuk negatif yang memiliki makna penegasian dan makna penilaian pribadi pembicara. Selain itu, ketiga fukushi tersebut memiliki arti yang hampir sama yaitu, "sama sekali tidak" atau "tidak sama sekali”. Penggunaan chittomo, kesshite dan zenzen dalam beberapa konteks kalimat tidak dapat saling menggantikan. Hal tersebut dikarenakan chittomo selalu diikuti dengan bentuk negatif yang mengandung makna penegasian dan penilaian pribadi pembicara. Kesshite diikuti dengan bentuk negatif atau ungkapan larangan yang mengandung makna penegasian serta berkaitan dengan keinginan pembicara. Kemudian zenzen, dapat digabungkan dengan bentuk negatif atau-pun positif yang mengandung makna penegasian dan penilaian pembicara.

\section{Daftar Pustaka}

Chaer, Abdul. 2014. Linguistik Umum. Jakarta : Rineka Cipta.

\section{Tata Bahasa Praktis}

Bahasa Indonesia. Jakarta : Rineka Cipta.

Makoto, Ei. 2003. Waseda Nihongo, Tokyo : Universitas Waseda.

Masuoka, Takashi dan Yukinori, Takubo. 1992. Kiso Nihongo Bunpou, Tokyo : Kuroshio.

Sunakawa, Yuriko. 1998. Nihongo Bunkei Jiten. Tokyo : Kuroshio. 
Verhaar, J.W.M. 2010. Asas-Asas

Linguistik Umum. Yogyakarta : Gadjah Mada University Press. 